\title{
Analisis Berpikir Siswa Level Van Hiele dalam Memecahkan Masalah Segiempat Berdasarkan Langkah Polya
}

\author{
Author: \\ Atik Robbana ${ }^{1}$ \\ Sunardi ${ }^{2}$ \\ Erfan Yudianto ${ }^{3}$ \\ Rachma Windasari ${ }^{4}$

\section{Affiliation:} \\ ${ }^{1}$ University of Jember, East \\ Java, Indonesia \\ ${ }^{2}$ SMPN 2 Jember, East Java, \\ Indonesia

\section{Corresponding author:} \\ Atik Robbana, \\ atikrobbana23@gmail.com
}

\section{Dates:}

Received: 15/8/2021

Accepted: 20/11/2021

Published: 30/11/2021

\begin{abstract}
Abstrak. Penelitian ini bertujuan untuk mendeskripsikan berpikir siswa level deduksi informal, deduksi, dan rigor dalam memecahkan masalah segiempat berdasarkan langkah Polya. Subjek penelitian ini adalah 3 siswa binaan olimpiade SMPN 2 Jember yang masing-masing berada pada level deduksi informal, deduksi, dan rigor. Siswa diberikan tes masalah geometrid an kemudian dilanjutkan dengan wawancara. Jenis penelitian ini adalah deskripstif kualitatif. Hasil penelitian menunjukkan bahwa siswa level deduksi informal, deduksi, dan rigor memenuhi semua indikator sesuai levelnya pada langkah memahami masalah dan menyusun rencana. Pada langkah melaksanakan rencana siswa deduksi informal tidak memenuhi tiga indikator sesuai levelnya dan siswa deduksi tidak memenuhi satu indikator sesuai levelnya, sedangkan siswa rigor tidak memenuhi dua indikator sesuai levelnya. pada langkah memeriksa kembali siswa level deduksi informal dan siswa level deduksi memenuhi semua indikator sesuai levelnya, sedangkan siswa rigor tidak memenuhi dua indikator sesuai levelnya.
\end{abstract}

Kata Kunci: Berpikir, Level Van Hiele, Memecahkan Masalah, Segiempat, Langkah Polya.

\begin{abstract}
This study aims to describe student's level thinking of understanding geometry according to van Hiele's theory (informal deduction, deduction, and rigor) in solving of a quadrilateral problems based on Polya's steps. The subjects of the study were 3 students Olympiad of SMPN 2 Jember, each of them have the level in informal deduction, deduction, and rigor. These students were given tests of geometry problem test at beginning and then proceeded to interview. The descriptive qualitative research was used in this study. The results showed that the subjects are able to fulfill all of the indicators according to their level in the step of understanding the problem and make arrangements. In part of carry out the plan, a student with informal deduction level is not able to solve the three indicators and a student with deduction levels is not able to solve one of the indicators, whereas the rigor's student is not to able accomplish two indicators according to the levels. In step of looking back, a student with informal deduction level and a student with deduction level are not capable to solve the whole of indicators, however the rigor's student is not able to accomplish two indicators according to the levels.
\end{abstract}

Keywords: Think,Van Hiele Levels, Solving of Problems, Quadrilateral, Polya's Steps

\section{Copyright:}

This work is licensed under a Creative Commons Attribution-ShareAlike 4.0 International License.

Read online:

https://jurnal.unej.ac.id/index.php/JOMEAL/index or scan barcode beside.

\section{How to cite this article:}

Robbana, A., Sunardi, S., Yudianto, E., \& Windasari, R. (2021). Analisis Berpikir Siswa Level Van Hiele dalam Memecahkan Masalah Segiempat Berdasarkan Langkah Polya. Journal of Mathematics Education and Learning, 1(3), 205-217. doi:10.19184/jomeal.v1i3.26100 


\section{Pendahuluan}

Matematika merupakan ilmu struktur, angka, serta hubungan yang mencakup dasar-dasar dalam perhitungan, pengukuran, dan penggambaran objek. Pengukuran dan penggambaran objek dalam matematika dipelajari mendalam pada salah satu cabang ilmu yaitu geometri. Geometri merupakan bagian dari matematika yang mempelajari tiga unsur dasar yaitu titik, garis, dan bidang (Afifah, dkk, 2019). Salah satu pokok bahasan pada geometri sekolah adalah bangun datar. Bangun datar adalah bangun yang mempunyai dimensi dua yaitu panjang dan lebar. Misalnya segitiga, segiempat, segilima, segienam dan seterusnya hingga segi- $n$.

Proses berpikir dalam pemecahan masalah kurang mendapat perhatian guru di dalam pembelajaran matematika (Alexander dan Koberlin, 2011). Tujuan pembelajaran matematika tidak hanya siswa dapat menjawab soal. Salah satu tujuan pembelajaran matematika adalah memecahkan masalah matematika yang meliputi kemampuan memahami masalah, menyusun model penyelesaian matematika, menyelesaikan model matematika, dan memberi solusi yang tepat (Arifah, dkk, 2019). Mengetahui proses berpikir siswa dalam menyelesaikan suatu masalah matematika sangat penting bagi guru (Alexander dan Koberlin, 2011). Guru harus memahami cara berpikir siswa dan mengolah informasi yang masuk sambil mengarahkan siswa untuk mengubah cara berpikirnya jika itu ternyata diperlukan. Guru harus mengetahui proses berpikir siswa dalam memecahkan masalah supaya pembelajaran yang direncanakan dapat berhasil dan meraih hasil maksimal. Pembelajaran matematika mengutamakan keterampilan proses dan strategi dalam menyelesaikan masalah. Salah satu strategi dalam pemecahan masalah matematika dikemukakan oleh Polya. Empat langkah penyelesaian masalah matematika menurut Polya yaitu langkah memahami masalah, merencanakan penyelesaian, melaksanakan rencana penyelesaian, dan memeriksa kembali kebenaran solusi (Ayuningrum, 2017).

Penelitian ini fokus pada materi segiempat. Segiempat adalah poligon yang mempunyai tepat empat sisi (Faradisa, dkk, 2018). Poligon atau disebut juga segi banyak adalah suatu kurva sederhana tertutup yang dibentuk oleh (terdiri atas) segmen garis-segmen garis (Indah, 2019). Segmen garis yang telah membentuk segi banyak disebut sisi. Sebuah poligon dengan sisi- $n$ dapat disebut segi- $n$.

Berikut ini merupakan penelitian mengenai kesulitan siswa dalam menyelesaikan permasalahan segiempat menyatakan bahwa salah satu faktor penyebab kesulitan siswa dalam menyelesaikan soalsoal segiempat yaitu siswa belum memahami konsep dari segiempat (Indraswari, 2020). Salah satu kesulitan dan faktor-faktor penyebab yang dialami subjek dalam menyelesaikan soal-soal segiempat adalah cenderung mengalami kesulitan dalam mempelajari konsep segiempat (Linda, dkk, 2020). Siswa kesulitan dalam mendefinisikan tiap-tiap bangun dan kesulitan juga dalam memahami hubungan yang terkait antara segiempat yang satu dengan segiempat yang lain (Nadjib, 2014).

Tingkatan kemampuan berpikir berdasarkan teori van Hiele ada 5 level, antara lain: level 0 (visualisasi), level 1 (analisis), level 2 (deduksi informal), level 3 (deduksi), dan level 4 (rigor) (Rahman, 2019). Penelitian yang mengaitkan antara kemampuan yang dimiliki siswa dengan level berpikir berdasarkan teori van Hiele telah dilakukan. Siswa tingkat deduksi informal dapat merumuskan dan menggunakan definisi, memberikan argumen informal dan mengatur urutan sifat yang diberikan sebelumnya (Pratiwi, Yunani, dan Wahyu, 2020). Penelitian yang mengungkapkan bahwa siswa pada level 2 deduksi informal mampu mendefinisikan bangun trapesium dengan bahasa sendiri (Rahman, dkk, 2019). 
Berdasarkan uraian di atas, dapat diketahui bahwa siswa masih kesulitan dalam menyelesaikan soal-soal dan mendefinisikan tiap-tiap bangun segiempat. Hal ini dikarenakan siswa belum memahami konsep segiempat. Oleh karena itu, peneliti akan melakukan penelitian dengan judul “Analisis Berpikir Siswa Level Van Hiele dalam Memecahkan Masalah Segiempat Berdasarkan Langkah Polya”.

\section{Metode Penelitian}

Jenis penelitian ini merupakan penelitian deskriptif dengan pendekatan kualitatif yaitu analisis data utamanya berupa kata-kata yang dirangkai menjadi sebuah kalimat. Penelitian ini menggunakan jenis penelitian kualitatif karena bermaksud untuk mengetahui dan mendeskripsikan berpikir siswa level van Hiele dalam memecahkan masalah segiempat berdasarkan langkah Polya. Penelitian ini dilakukan kepada siswa binaan olimpiade SMPN 2 Jember. Sampel penelitian sebanyak 8 siswa. Untuk menentukan subjek penelitian peneliti memberikan tes kemampuan siswa dalam geometri. Dari hasil tes tersebut kemudian dianalisis, didapatkan 1 siswa pada level 1 (analisis), 5 siswa pada level 2 (deduksi informal), 1 siswa pada level 3 (deduksi), dan 1 siswa pada level 4 (Rigor). Penentuan subjek penelitian menggunakan purposive sampling yaitu subjek yang dipilih tidak bersifat acak dan dengan pertimbangan-pertimbangan tertentu. Jumlah subjek penelitian adalah 3 siswa dengan 1 siswa berada pada level 2 (deduksi informal), 1 siswa berada pada level 3 (deduksi), dan 1 siswa berada pada level 4 (rigor). Subjek dikodekan S1 sebagai subjek yang berada pada level deduksi informal, S2 sebagai subjek level deduksi, dan S3 subjek level rigor.

Pada penelitian ini pengumpulan data dilakukan dengan metode tes dan wawancara. Tes yang digunakan pada penelitian ini ada dua, yaitu tes kemampuan siswa dalam geometri dan tes masalah geometri. Tes kemampuan siswa dalam geometri digunakan untuk mengetahui level berpikir geometri siswa, sedangkan tes masalah geometri digunakan untuk mengetahui berpikir siswa dalam memecahkan masalah segiempat. Wawancara digunakan untuk mengetahui lebih mendalam berpikir siswa dalam memecahkan masalah segiempat berdasarkan langkah Polya.

Analisis data hasil tes level kemampuan berpikir siswa dalam geometri menggunakan kriteria penskoran yang dikembangkan oleh Usiskin tahun 1982. Analisis data hasil tes masalah geometri menggunakan langkah analisis yang dikemukakan oleh Miles dan Huberman yang meliputi Reduksi data, penyajian data, dan penarikan kesimpulan (Sugiyono, 2013). Sedangkan langkah analisis data hasil wawancara yaitu reduksi data, triangulasi, penyajian data, dan penarikan kesimpulan.

Instrumen yang digunakan telah melalui uji validasi oleh validator. Validator instrumen merupakan dua dosen Program Studi Pendidikan Matematika. Hasil analisis tes masalah geometri didapatkan nilai $V_{a}=8,5$ sedangkan pedoman wawancara didapatkan nilai $V_{a}=8,7$. Hasil tersebut menunjukkan bahwa instrumen dapat dikatakan valid menurut tabel kevalidan.

\section{Hasil dan Pembahasan}

\section{A. Hasil}

Masalah geometri yang digunakan dalam penelitian ini adalah masalah segiempat mengenai definisi. Masalah tersebut telah disesuaikan dengan level berpikir siswa yang berada minimal pada level deduksi informal, yaitu mampu memformulasikan dan merumuskan definisi (Supriyadi, 
Mardiyana, dan Subanti, 2015). Berikut ini adalah tes masalah geometri yang digunakan pada penelitian ini.

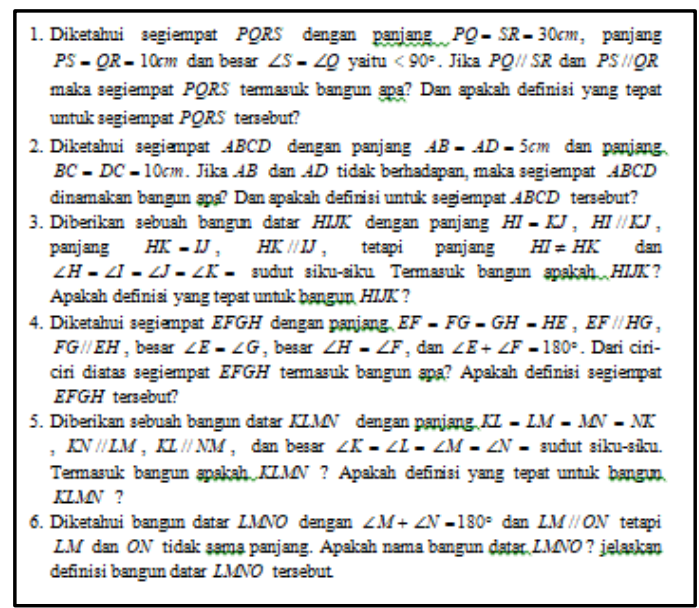

Gambar 1. Tes masalah geometri

\section{a. Analisis Data S1}

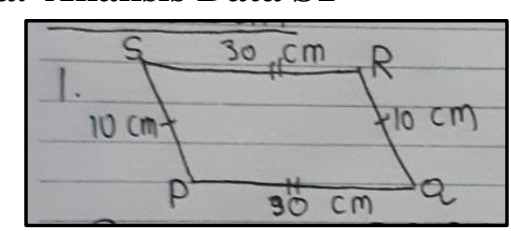

(a)

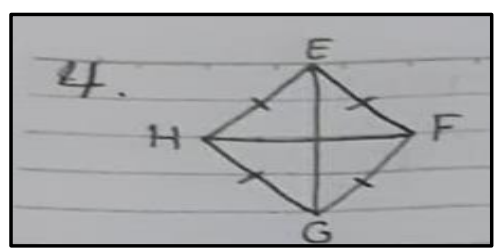

(d)

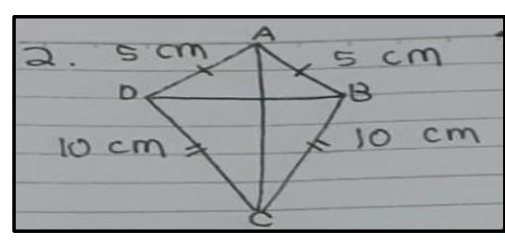

(b)



(e)

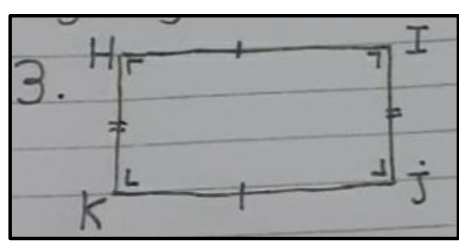

(c)

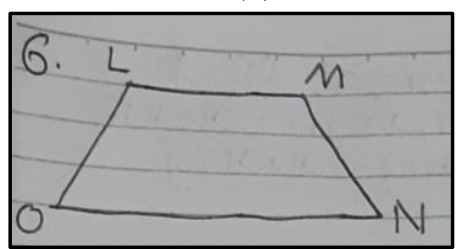

(f)

Gambar 2. Tahap memahami masalah S1 (a) soal nomor 1, (b) soal nomor 2, (c) soal nomor 3, (d) soal nomor 4, (e) soal nomor 5, dan (f) soal nomor 6

Saat memahami masalah S1 mambaca permasalahan 2-3 kali. S1 mampu mengidentifikasikan hal-hal yang diketahui dalam permasalahan dan menuangkannya ke dalam gambar. S1 memprediksi pengetahuan yang akan digunakan untuk menyelesaikan permasalahan yaitu dengan digambar. Hal ini sejalan dengan cuplikan wawancara berikut.

P147 Berapa kali Anda membaca soal? Mengapa?

S147 Saya membaca semua soal 2-3 kali dengan alasan agar lebih memahami maksud soal yang diberikan.

P178 Dari soal No. 6 informasi apa saja yang kamu dapatkan dan bagaimana cara menghubungkannya?

S178 Soal nomor 6 memberikan informasi mengenai ciri-ciri bangun segiempat, jika dihubungkan dengan digambar akan membentuk bangun trapesium. 
Pada langkah menyusun rencana S1 mampu menentukan rencana yang akan digunakan untuk menyelesaikan masalah dengan melibatkan pengetahuan yang didapat sebelumnya. S1 menjelaskan bahwa strategi untuk menyelesaikan permasalahan nomor 1 adalah dengan membaca soal agar memahami informasi dan pertanyaan, kemudian membayangkan dan menggambar di kertas lalu membuat definisi. S1 juga menyatakan bahwa strategi untuk soal nomor 2 sampai 6 sama seperti nomor 1. Hal tersebut sesuai dengan cuplikan wawancara dengan S1 berikut.

P105 Dari informasi tersebut bagaimana strategi penyelesaian yang terpikirkan oleh Anda untuk mengerjakan permasalahan tersebut?

S105 Pada soal nomor 1, saya membaca soal sekitar dua sampai tiga kali agar saya benar-benar mengetahui informasi dan pertanyaan yang ada dalam soal. lalu, saya membayangkan bangun datar dalam pikiran dengan menghubungkan informasi yang ada pada soal. Kemudian, saya gambar bangun datar yang saya dapat di kertas. Setelah itu, saya mencocokkan gambar saya dengan ciri-ciri dalam soal. Baru saya definisi dengan informasi yang telah didapatkan.

P120 Dari informasi tersebut bagaimana strategi penyelesaian yang terpikirkan oleh Anda untuk mengerjakan permasalahan No. 2?

S120 Untuk soal nomor dua sampai 6 strateginya sama seperti nomor 1.

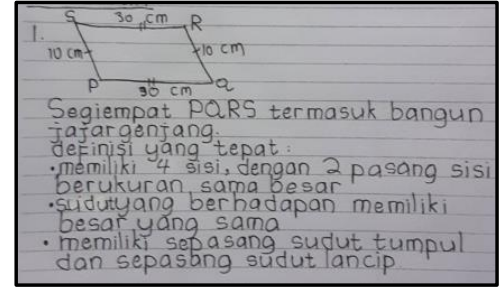

(a)

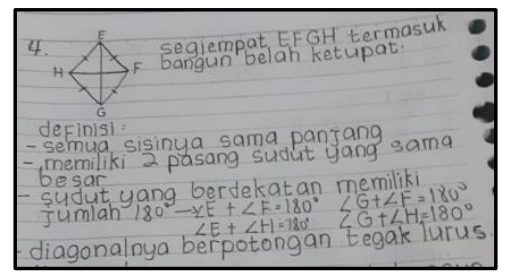

(d)

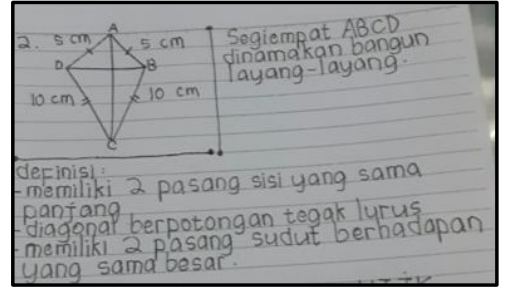

(b)

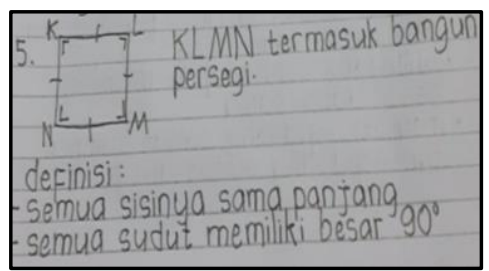

(e)

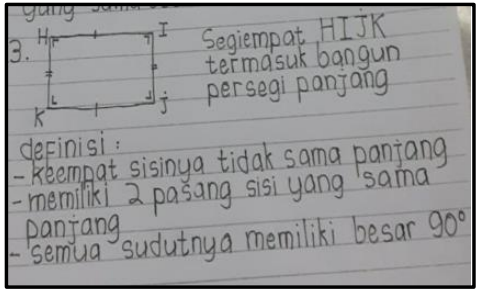

(c)

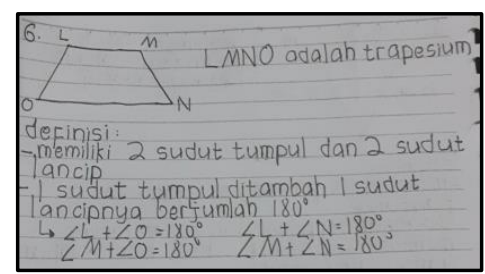

(f)

Gambar 3. Tahap melaksanakan rencana S1 (a) soal nomor 1, (b) soal nomor 2, (c) soal nomor 3, (d) soal nomor 4, (e) soal nomor 5, dan (f) soal nomor 6

Pada langkah melaksanakan rencana S1 mampu melibatkan pengetahuan yang didapat sebelumnya dari soal dengan tepat untuk menyelesaikan masalah. S1 mampu mengonstruk penyelesaian masalah. S1 jugaa mampu mengerjakan dan menjelaskan jawaban penyelesaian secara runtut. S1 memperoleh hasil atau jawaban dari tujuan masalah yang diberikan. Hal ini sejalan dengan cuplikan wawancara berikut.

P108 Jelaskan bagaimana langkah-langkah dalam menyelesaikan soal nomor 1 yang terdapat pada tes tersebut? 
S108 Pertama, saya membaca soal berulang-ulang kali agar benar-benar memahami permasalahan yang diberikan, yang kedua saya membayangkan bentuk segiempat berdasarkan ciri-ciri yang ada disoal mendapatkan bangun datar jajargenjang, yang ketiga saya mulai menggambar bangun jajargenjang berdasarkan ciri-ciri pada soal, lalu menyusun definisi berdasarkan informasi yang telah didapat, terakhir saya mengoreksi ulang.

Pada langkah memeriksa kembali, S1 memeriksa kembali jawaban dari permasalahan yang diberikan. S1 memeriksa kembali jawabannya dengan cara membaca kembali soal agar tidak ada kesalahan dalam proses pengerjaan dan S1 juga mengoreksi jawabannya agar tidak ada yang salah. Hal ini sesuai dengan wawancara yang telah dilakukan berikut ini.

P112 Bagaimana cara yang Anda lakukan untuk memeriksa kembali jawaban yang telah didapat? Misalkan dengan membaca kembali jawaban yang Anda peroleh, atau bagaimana?

S112 Saya membaca kembali soal agar tidak ada kesalahan dalam proses pengerjaan dan saya juga mengoreksi jawaban agar tidak ada yang salah.

\section{b. Analisis Data S2}

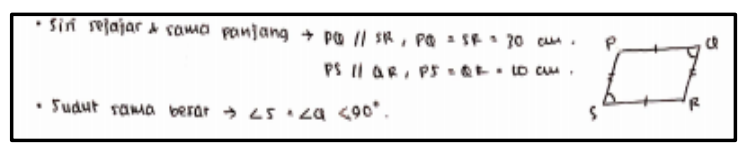

(a)

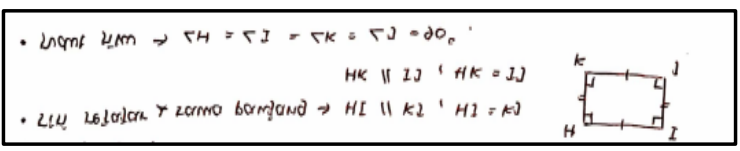

(c)

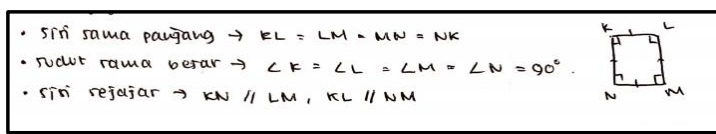

(e)

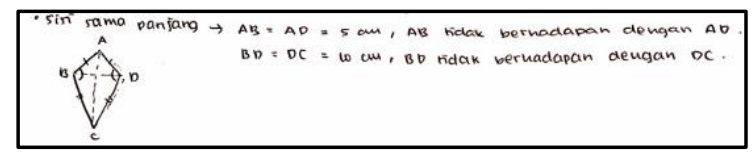

(b)

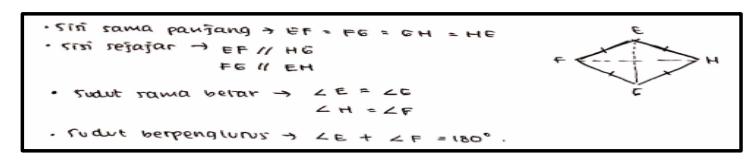

(d)

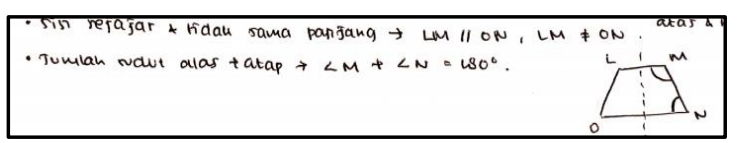

(f)

Gambar 4. Tahap memahami masalah S2 (a) soal nomor 1, (b) soal nomor 2, (c) soal nomor 3, (d) soal nomor 4, (e) soal nomor 5, dan (f) soal nomor 6

Pada langkah memahami masalah, S2 dapat mengidentifikasi hal-hal yang diketahui pada soal dengan menuliskan dan menjelaskan yang diketahui pada soal dengan benar dan lengkap. S2 menuangkan hal-hal yang diketahui ke dalam gambar. S2 membaca permasalahan dua kali dengan alasan karena takut tidak teliti. S2 juga dapat memprediksi penyelesaian dari permasalahan. Hal ini sesuai dengan cuplikan wawancara berikut.

P202 Berapa kali Anda membaca soal? Mengapa?

S202 Sekitar 2 kali, karena takut tidak teliti.

P203 Dari soal No. 1, informasi apa saja yang kamu dapatkan atau yang diketahui pada soal dan bagaimana cara kamu menghubungkannya? 
S203 Soal No. 1 memberikan informasi $P Q=S R=30 \mathrm{~cm}, P S=Q R=10 \mathrm{~cm}, \angle S=\angle Q<90^{\circ}$, $P Q / / S R, P S / / Q R$. Cara menghubungkannya dengan mencermati informasi yang diberikan kemudian menentukan bangun datar sesuai ciri-ciri dari informasi tersebut.

Pada langkah menyusun rencana S2 mampu menentukan rencana yang akan digunakan untuk menyelesaikan masalah dengan melibatkan pengetahuan yang didapat sebelumnya. S2 juga dapat menjelaskan bahwa strategi untuk menyelesaikan permasalahan. Hal tersebut sesuai dengan cuplikan wawancara dengan S2 berikut.

P205 Dari informasi tersebut bagaimana strategi penyelesaian yang terpikirkan oleh Anda untuk mengerjakan permasalahan No. 1 tersebut?

S205 Langsung saya gabungkan informasinya menjadi ciri-ciri sebuah bangun datar, kemudian definisinya saya jabarkan dari informasi pada soal.

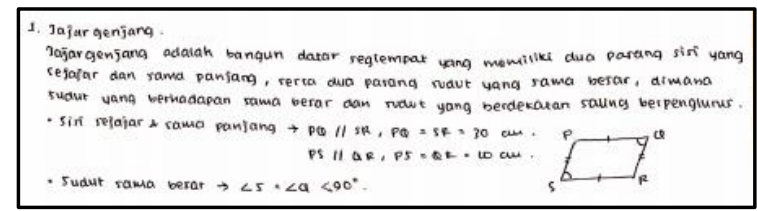

(a)

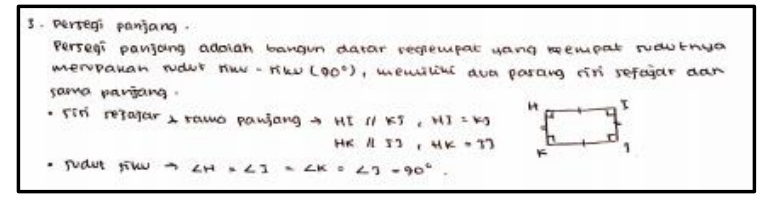

(c)

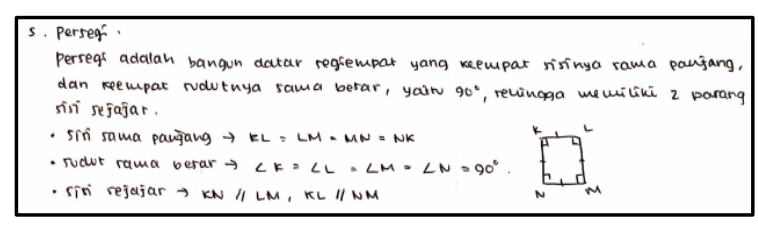

(e)

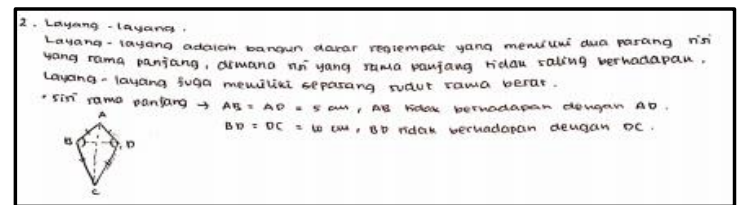

(b)

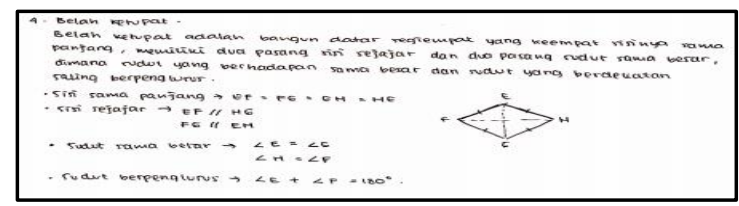

(d)

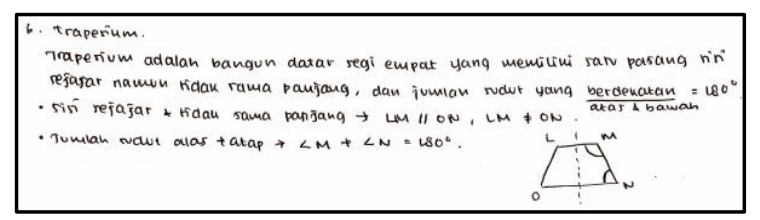

(f)

Gambar 5 Tahap melaksanakan rencana S2 (a) soal nomor 1, (b) soal nomor 2, (c) soal nomor 3, (d) soal nomor 4, (e) soal nomor 5, dan (f) soal nomor 6

Pada langkah melaksanakan rencana, S2 mampu menyelesaikan masalah sesuai dengan rencananya dan memperoleh jawaban yang diharapkan. S2 juga dapat menjelaskan langkah penyelesaian dengan lancar. S2 pun memperoleh jawaban dari permasalahan yang diberikan. S2 juga mempunyai cara atau strategi lain untuk menyelesaikan soal. Hal ini sesuai dengan cuplikan wawancara berikut.

P207 Apakah ada kemungkinan strategi lain yang Anda ketahui?

S207 Ya... mungkin bisa digambar sesuai dengan ciri-ciri yang sudah didapat dari informasi pada soal.

P208 Jelaskan bagaimana langkah-langkah dalam menyelesaikan soal No. 1 yang terdapat pada tes tersebut? 
S208 No. 1 didapatkan informasi bahwa $P Q=S R, P Q / / S R, P S=Q R, P S / / Q R$ maka $P Q R S$ segiempat dan dua pasang ruas garis sejajar dan sama panjang. $\angle S=\angle Q<90^{\circ}$ maka sudut yang bersebrangan sama besar $\neq 90^{\circ}$. Nah dari informasi tersebut sudah dapat ditentukan bahwa bangun yang dimaksud adalah jajargenjang, kemudian definisinya saya susun dari informasi pada soal.

S2 pada langkah memeriksa kembali, S2 memeriksa jawaban dari permasalahan yang diberikan. S2 memeriksa kembali jawabannya dengan memeriksa kembali soal yang diberikan dan memeriksa kembali jawaban apakah sudah sesuai dengan hasil yang dipikirkan. S2 juga dapat memberikan kesimpulan. Hal ini sesuai dengan wawancara yang telah dilakukan berikut ini.

P212 Bagaimana cara yang Anda lakukan untuk memeriksa kembali jawaban yang telah didapat? Misalkan dengan membaca kembali jawaban yang Anda peroleh, atau bagaimana?

S212 Dengan memeriksa kembali soal yang diberikan dan memeriksa jawaban apakah sudah sesuai dengan hasil yang saya pikirkan.

P215 Apakah kesimpulan yang Anda dapatkan dari permasalahan yang ada pada tes?

S215 Jajargenjang adalah bangun datar segiempat yang memiliki dua pasang sisi sejajar dan sama panjang, serta dua pasang sudut sama besar, dimana jumlah sudut yang berdekatan $180^{\circ}$ dan sudut yang berhadapan sama besar.

\section{c. Analisis Data S3}

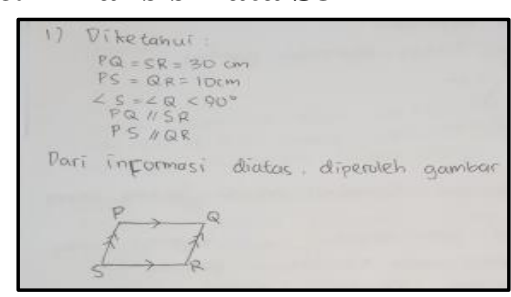

(a)

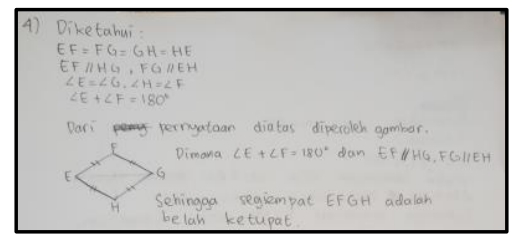

(d)

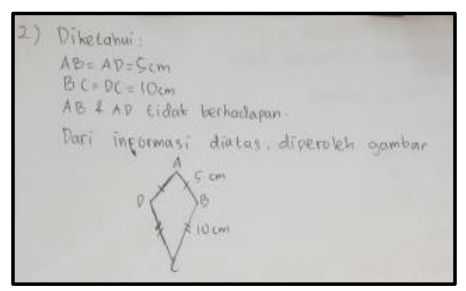

(b)

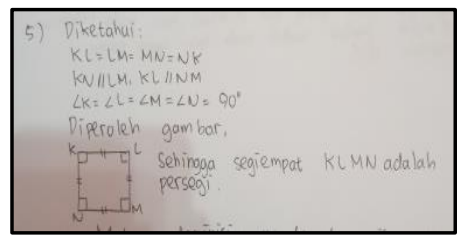

(e)

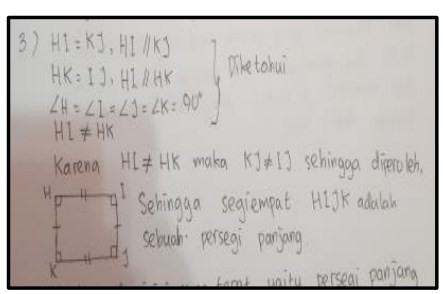

(c)

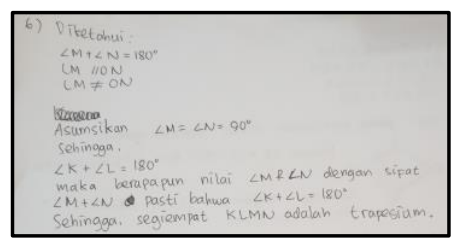

(f)

Gambar 6. Tahap memahami masalah S3 (a) soal nomor 1, (b) soal nomor 2, (c) soal nomor 3, (d) soal nomor 4, (e) soal nomor 5, dan (f) soal nomor 6

Pada langkah memahami masalah S3 dapat mengidentifikasi hal-hal yang diketahui pada soal dengan menuliskan hal yang diketahui dengan benar dan lengkap. S3 juga menunangkan hal yang diketahui tersebut kedalam gambar. S3 membaca permasalahan tiga sampai lima kali. S3 dapat memprediksi penyelesaian dari permasalahan. Hal ini sesuai dengan cuplikan wawancara berikut.

P302 Berapa kali Anda membaca soal? Mengapa?

S302 3-5 kali Bu..

P304 Dari soal, informasi apa saja yang kamu dapatkan dan bagaimana cara kamu menghubungkannya?

S304 Untuk nomor 1 yang saya dapatkan adalah panjang sisi dan sudut segiempat. Saya menghubungkannya dengan mengilustrasikan dan memahami informasi yang diberikan. 
Pada langkah menyusun rencana, S3 mampu menentukan rencana yang akan digunakan untuk menyelesaikan masalah dengan melibatkan pengetahuan yang didapat sebelumnya. S3 dapat menjelaskan bahwa strategi penyelesaian permasalahan. Hal tersebut sesuai dengan cuplikan wawancara dengan S3 berikut.

P306 Dari informasi tersebut bagaimana strategi penyelesaian yang terpikirkan oleh Anda untuk mengerjakan permasalahan tersebut?

S306 Dari informasi yang telah didapat saya membuat kesimpulan, lalu saya gambarkan sesuai informasi, kemudian saya dapat menentukan bangun apa dan definisi bangun tersebut.

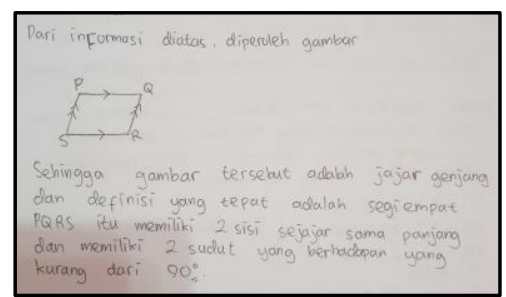

(a)

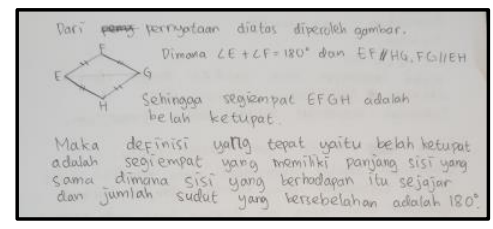

(d)

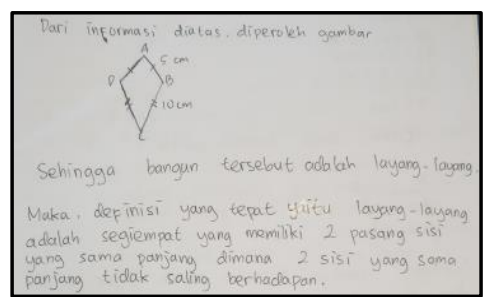

(b)

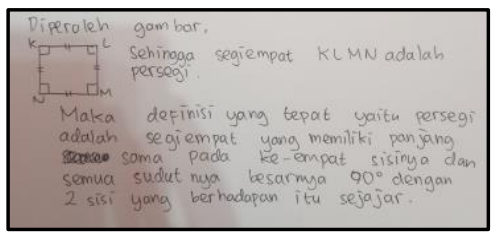

(e)

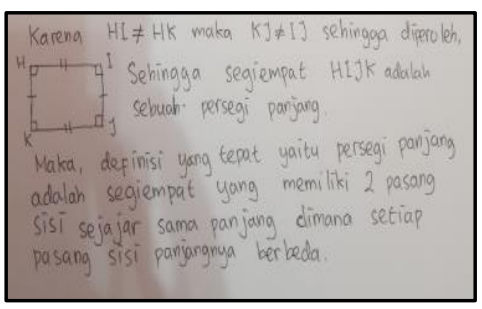

(c)

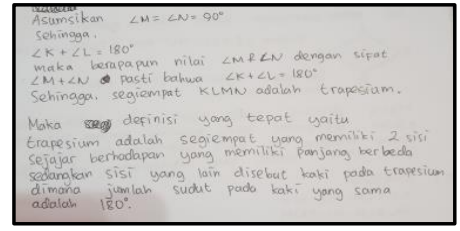

(f)

Gambar 7. Tahap memahami masalah S3 (a) soal nomor 1, (b) soal nomor 2, (c) soal nomor 3, (d) soal nomor 4, (e) soal nomor 5, dan (f) soal nomor 6

Pada langkah melaksanakan rencana, S3 mampu menyelesaikan masalah sesuai dengan rencananya. S3 melibatkan pengetahuan yang didapat sebelumnya dengan tepat dalam menyelesaikan masalah. S3 juga dapat menjelaskan langkah-langkah penyelesaian permasalahan dengan runtut. S3 pun memperoleh jawaban dari permasalahan yang diberikan. Hal ini sejalan dengan cuplikan wawancara berikut.

P309 Jelaskan bagaimana langkah-langkah dalam menyelesaikan soal yang terdapat pada tes tersebut?

S309 Pertama saya membaca soal dan mencari informasi disoal. Lalu saya coba ilustrasikan dengan memperhatikan informasi yang diberikan. Setelah saya mengetahui bahwa bangun tersebut jajargenjang. Saya susun definisi sesuai informasi yang diberikan.

Pada langkah memeriksa kembali, S3 tidak memeriksa kembali jawaban dari permasalahan yang diberikan dari soal nomor 1 sampai nomor 6. S3 mengetahui bahwa jawaban yang diperoleh adalah benar. Namun, meskipun S3 tidak memeriksa jwabannya S3 memberikan kesimpulan untuk permasalahan yang diberikan. Hal ini sesuai dengan wawancara dengan S3 berikut ini.

P312 Apakah Anda memeriksa atau mengoreksi kembali jawaban yang diperoleh? Jika tidak, apa alasannya?

S312 Tidak, karena dengan langkah-langkah tersebut saya juga sambil mengoreksi pekerjaan yang saya kerjakan.

P314 Apakah kesimpulan yang Anda dapatkan dari permasalahan yang ada pada tes? 
S314 Jajargenjang adalah segiempat yang memiliki sisi sehadap sama panjang dan sepasang sudut berhadapan sama yang $<90^{\circ}$

\section{B. Pembahasan}

Langkah Polya yang pertama adalah memahami masalah. S1 merupakan subjek penelitian yang berada pada level 2 (deduksi informal). S1 mampu memahami permasalahan yang diberikan dengan membaca soal beberapa kali. S1 juga mampu mengidentifikasi hal-hal yang diketahui dan ditanya dalam permasalahan dan menuangkannya ke dalam gambar (Widyaningsih, Zaenuri, dan Dwijanto, 2020). Gambar yang S1 buat sudah jelas karena disertai keterangan. S1 tidak mendapatkan kesulitan yang berarti, karena S1 sudah pernah menjumpai permasalahan yang serupa. Oleh karena itu, S1 juga mampu memprediksi pengetahuan yang akan digunakan untuk menyelesaikan permasalahan. Hal ini berarti S1 memenuhi indikator pada langkah memahami masalah sesuai levelnya (Wulan dan Rosidah, 2020). S2 yang merupakan subjek penelitian yang berada pada level 3 (deduksi) mampu memahami permasalahan dengan hanya membaca 2 kali permasalahan yang diberikan. S2 juga mampu mengidentifikasi hal-hal yang diketahui dalam permasalahan dengan menuliskan dan menuangkannya ke dalam gambar (Walle, dkk, 20160. Gambar yang S2 buat sudah cukup jelas. S2 juga mampu memprediksi penyelesaian dari permasalahan yaitu dengan menghubungkan apa yang diketahui pada soal sehingga membentuk suatu bangun datar. S2 tidak mengalami kesulitan dalam menyelesaikan permasalahan walaupun S2 belum pernah menjumpai permasalahan yang serupa. Hal ini berarti, S2 memenuhi indikator pada langkah memahami masalah sesuai levelnya. S3 merupakan subjek penelitian yang berada pada level 4 (rigor). S3 mampu memahami permasalahan yang diberikan dengan membaca beberapa kali pemasalahan yang diberikan. S3 mampu mengidentifikasi hal-hal yang diketahui pada soal dengan menuliskan dan meuangkannya ke dalam gambar. Gambar yang S3 buat sudah cukup jelas. S3 juga mampu memprediksi penyelesaian dari permasalahan yaitu dengan cara di gambar atau metode pembuktian. S3 hanya mengalami kesulitan beberapa saja karena S3 sudah pernah menjumpai permasalahan yang serupa sebelumnya. Hal ini menunjukkan bahwa S3 memenuhi indikator pada langkah memahami masalah sesuai levelnya.

Langkah kedua adalah menyusun rencana. S1 mampu menentukan rencana yang akan digunakan untuk menyelesaikan masalah dengan melibatkan pengetahuan yang didapat sebelumnya yaitu dengan menuangkan apa yang diketahui pada gambar. Strategi penyelesaian yang digunakan oleh S1 adalah menggambarkan bangun segiempat yang dimaksud oleh soal, dilanjutkan dengan mencocokkan sesuai pengetahuan S1 termasuk segiempat apakah yang dimaksud pada soal (Sumiati dan Agustin, 2020). Strategi yang digunakan oleh S1 merupakan strategi yang tepat dan mudah. Hal ini menunjukkan bahwa S1 mampu memenuhi semua indikator pada langkah menyusun rencana. S2 dan S3 juga mampu menyusun rencana penyelesaian masalah dengan mengumpulkan informasi yang didapat pada soal, lalu menghubungkannya sehingga membentuk bangun datar dengan cara digambarkan. Strategi penyelesaian yang digunakan S2 dan S3 sudah tepat dan mudah. S2 dan S3 mampu memenuhi semua indikator pada langkah menyusun rencana.

Langkah selanjutnya adalah melaksanakan rencana. S1 melaksanakan rencana sesuai dengan rencana yang telah dibuat sebelumnya yaitu dengan membuat gambar sesuai dengan informasi yang terdapat pada soal dan kemudian mendefinisikan bangun tersebut sesuai dengan gambar dan keterangan pada soal. Siswa level deduksi informal mampu mengenal segiempat berdasarkan gambar [1]. S1 dapat mengonstruk strategi penyelesaian dan mengerjakan permasalahan yang diberikan sehingga mendapatkan jawaban. Tetapi, S1 belum memenuhi semua indikator pada langkah 
melaksanakan rencana. S1 belum memenuhi indikator mempunyai cara lain untuk menyelesaikan permasalahan, mendefinisikan bangun secara lengkap, dan memahami struktur hubungan antar bangun. S2 melaksanakan rencana sesuai dengan rencananya. S2 mendapatkan jawaban dalam menyelesaikan permasalahan. S2 dapat mengonstruk strategi penyelesaian dari permasalahan. S2 mengerjakan dan menjelaskan jawaban penyelesaian secara runtut. Langkah-langkah penyelesaian yang dilakukan oleh S2 soal nomor 1, 3, 4, dan 5 sama yaitu dengan menggabungkan informasi yang didapat, kemudian menentukan nama bangun dengan memperhatikan ciri-ciri bangun datar yang diberikan pada soal, kemudian definisi disusun berdasarkan informasi pada soal. Sedangkan langkah penyelesaian nomor 2 sama seperti nomor 6 yaitu mengumpulkan informasi yang didapat pada soal, menghubungkannya menjadi sebuah gambar agar dapat menentukan nama bangun, kemudian definisi disusun berdasarkan informasi pada soal. S2 juga mempunyai cara lain untuk menyelesaikan permasalahan yang diberikan. Dari definisi segiempat yang telah dibangun oleh S2 menunjukkan bahwa S2 mengakui perlunya unsur-unsur pangkal (undefined terms) dan postulat dalam memecahkan permasalahan dan S2 mengenal karakteristik dari definisi formal (syarat perlu dan syarat cukup) dan S2 mampu memberikan argument deduktif formal. Namun, S2 belum memenuhi semua indikator pada langkah melaksanakan rencana karena S2 tidak menguji perubahan definisi awal atau postulat dalam urutan logis. S3 mampu melaksanakan rencana sesuai dengan rencananya dan memperoleh jawaban yang diharapkan. S3 dapat mengonstruk strategi penyelesaian masalah. Langkah-langkah yang dilakukan oleh S3 dalam menyelesaikan permasalahan pada soal nomor 1, 2, 3, dan 6 sama adalah membaca soal dan mencari informasi disoal. lalu diilustrasikan dengan memperhatikan informasi yang diberikan, kemudian S3 mengetahui nama bangun yang ditanyakan, selanjutnya S3 susun definisi sesuai informasi yang diberikan. Sedangkah langkah penyelesaian soal nomor 4 sama dengan soal nomor 5 yaitu memahami informasi yang ada kemudian membuat kesimpulan dari informasi tersebut, lalu menentukan nama bangun berdasar informasi dan dilanjutkan dengan menyusun definisi sesuai informasi. Langkah-langkah yang dilakukan oleh S3 menunjukkan bahwa S3 menggunakan logika dalam memecahkan masalah. S3 mengakui perlunya unsur-unsur pangkal (undefined terms), mengenal karakteristik dari definisi formal dan mampu memberikan argument deduktif formal. Namun, S3 belum memenuhi semua indikator pada langkah melaksanakan rencana karena S3 belum memenuhi indikator mempunyai cara lain untuk menyelesaikan permasalahan dan menguji perubahan definisi awal atau postulat dalam urutan logis.

Langkah terakhir adalah memeriksa kembali. S1 memenuhi semua indikator pada langkah memeriksa kembali. S1 mengoreksi kembali jawaban yang didapatkan dengan membaca kembali soal agar tidak terjadi kesalahan dalam proses pengerjaan dan juga mengoreksi jawaban. Siswa pada level 2 (deduksi informal) mampu melihat kembali proses dan hasil yang diperoleh (Wulan dan Rosidah, 2020). S1 juga dapat menjelaskan kesimpulan dari permasalahan. S2 dapat memenuhi semua indikator pada langkah memeriksa kembali. S2 mengoreksi kembali jawaban yang didapatkan. S2 menguji bahwa jawaban yang diperoleh sesuai dengan apa yang ditanyakan. S2 juga menjelaskan kesimpulan dari permasalahan dengan tepat. S3 belum memenuhi semua indikator pada langkah memeriksa kembali karena S3 tidak mengoreksi kembali jawaban yang didapat, S3 tidak menguji bahwa jawaban yang diperoleh sesuai dengan apa yang ditanyakan. Namun, S3 dapat menjelaskan kesimpulan dari permasalahan dengan tepat. 


\section{Kesimpulan}

Hasil penelitian menunjukkan bahwa siswa level deduksi informal memenuhi semua indikator pada langkah memahami masalah, menyusun rencana dan memeriksa kembali, sedangkan pada langkah melaksanakan rencana siswa deduksi informal tidak memenuhi tiga indikator sesuai levelnya yang telah dikaitkan dengan tahapan pemecahan masalah Polya dalam memecahkan masalah segiempat. Hal ini membuktikan bahwa siswa level deduksi informal telah melewati semua langkah pada tahapan pemecahan masalah Polya dengan baik, namun masih belum mempunyai cara lain untuk memecahkan masalah segiempat, mendefinisikan bangun secara lengkap, dan memahami struktur hubungan antar bangun. Siswa level deduksi memenuhi semua indikator sesuai levelnya pada langkah memahami masalah, menyusun rencana, dan memeriksa kembali, namun siswa deduksi belum memenuhi satu indikator pada langkah melaksanakan rencana. Hal ini menunjukkan bahwa siswa level deduksi telah melewati semua langkah pada tahap pemecahan masalah Polya dengan baik, namun belum dapat menguji perubahan definisi awal atau postulat dalam urutan logis. Siswa level rigor memenuhi semua indikator sesuai levelnya pada langkah memahami masalah dan menyusun rencana, namun pada langkah melaksanakan rencana siswa level rigor belum memenuhi dua indikator sesuai levelnya. Pada langkah memeriksa kembali siswa level rigor tidak memenuhi dua indikator sesuai levelnya. Hal ini menunjukkan siswa level rigor telah melewati semua langkah pada tahapan pemecahan masalah Polya, namun masih belum dapat menguji perubahan definisi awal atau postulat dalam urutan logis dan belum menemukan cara lain untuk memecahkan masalah segiempat. Pada langkah memeriksa kembali siswa level rigor juga tidak mengoreksi kembali jawaban yang diperoleh dan tidak menguji bahwa jawaban yang diperoleh sesuai dengan apa yang ditanyakan.

\section{Daftar Pustaka}

Afifah, A. H., Susanto., Sugiarti, T., Sunardi., dan Monalisa, L. (2019). Analisis Keterampilan Geometri Siswa Kelas X Dalam Menyelesaikan Soal Segiempat Berdasarkan Level van Hiele. Kadikma, 10(3), 35-47.

Alexander, D. C., dan Koberlein, G. M. (2011). Elementary Geometry For Collage Students (5th ed.). Canada: Nelson Education.

Arifah, Sri., Mampouw, H. L., dan Setyadi, D. (2019). Profil Penyelesaian Soal Trapesium oleh Mahasiswa PGSD ditinjau dari Level Berpikir van Hiele. Prosiding Sendika. Universitas Kristen Satya Wacana.

Ayuningrum, D. (2017). Strategi Pemecahan Masalah Matematika Siswa SMP Ditinjau dari Tingkat Berpikir Geometri Van Hiele. Kreano, 8 (1), 27-34.

Faradisa, Miftah., Z, M. Sulistio., dan Ayu, Y. Astri. (2018). Penggunaan Aplikasi Geogebra pada Pembeljaran Matematika Materi Poligon dan Sudut Sebagai Sarana Meningkatkan Kemampuan Siswa. Jurnal Equation, 1(2), 166-172.

Indah, Amaliyatul. (2019). Analsis berpikir siswa SMK Jurusan Teknik Desain Pemodeln dan Informasi Bangunan dalam Memecahkan Masalah Dimensi Tiga Berdasarkan Van Hiele. Skripsi. Universitas Jember.

Indraswari, Lulun., Lestari, A. Wiji., dan Hastari, R. Candra. (2020). Kesulitan Siswa dalam Menyelesaikan Soal-Soal Materi Segiempat dan Segitiga Ditinjau dari Gender. Jurnal Ilmiah Pendidikan Matematika, 7(2), 65-72. 
Linda., Bernard, Martin., dan Fitriani, Nelly. (2020). Analisis Kesulitan Siswa SMP Kelas VIII pada Materi Segiempat dan Segitiga Berdasarkan Tahapan Berpikir Van Hiele. Journal of Medive, 4 (2), 233-242.

Nadjib, A. (2014). Analisis Kesalahan Pemahaman Dalam Materi Segi Empat Menurut Tingkat Berpikir van Hiele pada siswa SMP Negeri 1 Suppa Kabupaten Pinarang. Pepatuzdu, 8(1), 1423.

Permendikbud. (2016). Standar Proses Lulusan Pendidikan Dasar dan Menengah (Permendikbud No. 22 tahun 2016). Jakarta: Permendikbud.

Pratiwi, N. Yuliani., dan Hidayat, Wahyu. (2020). Kesulitan Siswa Madrasah Ibtidaiyah pada Materi Pecahan Berdasarkan Langkah Polya. Jurnal Nasional Pendidikan Matematika, 4(2), 248-262.

Rahman, H. S., dkk. (2019). Scaffolding Profile in Solving Geometry Problems in Terms of van Hiele Level. Journal of Physics, 1-10.

Sugiyono. (2013). Metode Penelitian Kuantitatif, Kualitatif dan RnD. Bandung: Alfabeta CV.

Sumiati, A.l., dan Agustini, Y. (2020). Analisis Kesulitan Menyelesaikan Soal Segiempat dan Segitiga Siswa SMP Kelas VIII di Cianjur. Jurnal Cendikia, 4 (1), 321-330.

Supriadi, D., Mardiyana., dan Subanti, S. (2015). Analisis Proses Berpikir Siswa Dalam Memecahkan masalah matematika Berdasarkan Langkah Polya Ditinjau Dari Kecerdasan Emosional Siswa Kelas VIII SMP Al Azhar Shifa Budi Tahun Pelajaran 2013/2014. Elektronik Pembelajaran Matematika, 3(2), 204-214.

Usikin, Z. (1982). Van Hiele Levels and Achievement in Secondary School Geometry. Chicago: The University of Chicago.

Walle, J. A. Van De., Karp, K. S., dan Wray, J. (2016). Elementary and Middle School Mathematics Teaching Developmentally 9th Edition. United States of America: Person Education.

Widiyaningsih, E., Zaenuri., dan Dwijanto. (2020). Problem Solving Ability and Self Efficacy Based On Geometry Thinking Level In Van Hiele Learning. Journal of Mathematic Education Research, 9(2), 163-169.

Wulan, E. R., dan Rosidah, N. (2020). Bagaimana Problem Solving Geometri Ruang dari Level Berpikir Van Hiele Siswa?. Jurnal Ilmiah Pendidikan Matematika, 2(1), 22-40. 